\title{
Russian speech
}

\section{John C. Marshall}

Thought and Language. By Lev Vygotsky. Revised and edited by Alex Kozulin. MIT Press: 1986. Pp. 287. Hbk \$27.50, £24.75; pbk\$9.95, £8.95.

WHEN Vladimir Mayakovsky killed himself in 1930, the great Russian linguist Roman Jakobson commemorated his achievements in an impassioned essay "On a Generation That Squandered Its Poets". And not only its poets.

Between the Fourth Duma, summoned in 1912 by Tsar Nicholas II, and the imposition of Stalin's tyranny in the late 1920 s, the creative potential of the Russian peoples flowered as never before (or since). Despite war and revolution, censorship and economic chaos, the intelligentsia somehow managed to keep in close contact with the avant-garde of Western Europe whilst making signal contributions to all the arts, to linguistics and to psychology. The charismatic leader of Soviet psychology in this generation that had the misfortune to live in interesting times was Lev Vygotsky.

Born near Minsk in 1896 (the same year as Jakobson), Vygotsky graduated from the local Jewish gymnasium with honours

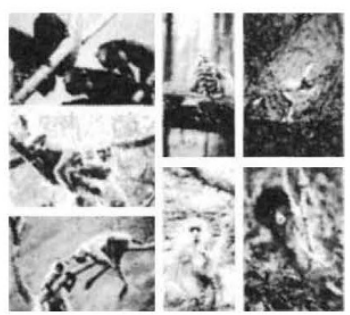

\section{Primate Societies}

Edited by BARBARA B. SMUTS, DOROTHY L. CHENEY, ROBERT M. SEYFARTH, RICHARD W. WRANGHAM \& THOMAS T. STRUHSAKER

With contributions from 46 experts, spanning the disciplines of behav ioural biology, ecology, anthropology and psychology, Primate Societies is the most systematic, detailed description and analysis available of social behaviour across the entire order of nonhuman primates.

c. $\$ 48.00$ Cloth 608pp illus. 0-226-76715-9

£19.95 Paper 0-226-76716-7 Publication: 3 /uly

THE UNIVERTTY (OF CHICAGO PRESS

126 Buckingham Palace Kead I onden SWiwesl) Reader Service No.42 and was awarded a gold medal for outstanding all-round achievement. Yet it was by sheer luck that he was admitted to Moscow University; the Jewish quota was 3 per cent - to be chosen by lottery. The dice fell in Vygotsky's favour. He intended to study philosophy (Hegel and Spinoza, in particular), but at his parents' prompting ("From philosophy you can earn a living?") entered first the Medical School and shortly thereafter transferred to the Law School. His law studies did not, however, prevent him from participating fully in the artistic life of Moscow, nor from enrolling at a private university, Shaniavsky, from which he graduated in history and philosophy.

After his student years in Moscow (1913-1917), Vygotsky moved to Gomel (1918-1924), where he first taught school children and then lectured at the local teachers' college. It was here that his interest in developmental psychology and in the education of the physically and mentally handicapped began to dominate his work. An earlier fascination with literary creation and criticism persisted, and Vygotsky concurrently finished a dissertation, The Psychology of Art, for which he was awarded a PhD from the Moscow Institute of Psychology.

Professional recognition came in 1924 , after a lecture he delivered to the Second Psychoneurological Congress in Leningrad. This talk - "The Methodology of Reflexological and Psychological Studies" - attacked the official Soviet doctrine that 'consciousness' was merely "an idealist superstition", as Kozulin writes, suitable at best for the "nonscientific psychology" in which one's grandmother is likely to believe. The lecture made a profound impression upon Alexander Luria, whose later studies of the cognitive effects of traumatic brain damage sustained by Russian soldiers in the Second World War are one of the cornerstones of modern neuropsychology (and in all probability saved him from the Gulag). Luria was instrumental in obtaining a position at the Moscow Institute for Vygotsky, and always regarded his own work as a continuation of Vygotsky's.

For the remaining decade of his life, Vygotsky worked and wrote like a demon, despite severe illness and the odium of both the psychological and political establishment. Although he did publish during his lifetime, at least $80 \mathrm{manu}$ scripts remained unpublished and only began to surface in the Soviet Union after 1956.

Thought and Language, Vygotsky's last and best-known work, appeared in the year of his death (1934), but was suppressed, along with all his other writings, two years later. This new English edition is required reading for all psychologists, East and West. The translation has been thoroughly overhauled, and extensive notes fill out the sometimes obscure references that still littered the text on Vygotsky's untimely death. Alex Kozulin has furthermore provided an introductory essay that sets Vygotsky's life and work in context for the Western scholar who expects his or her own work to provoke no government reaction more extreme than benign neglect.

What claims, then, does Thought and Language make, and why should they have been regarded as subversive? Vygotsky attacks the work of Jean Piaget, and argues that the young child is not as 'illogical' as Piaget makes out, provided that he or she is familiar with the situations, words and things that the investigator is manipulating. Different societies and social milieux will provide differential access to knowledge and experience. Hence, as Vygotsky writes, "One may imagine how substantial must be the differences in data collected in Genevan and Soviet kindergartens". Should Vygotsky have said that the Soviet data were 'better' than the Swiss, rather than merely different?

Vygotsky then criticizes William Stern's account of the child's first words. For Stern, the single word "Mama" can be translated as "Mama, come here" or "Mama, put me in the chair". No, says Vygotsky, there is no evidence for such intellectual underpinnings. Thought, affect and language develop independently. Only later do they converge in a 'symbolic' system that enables the child to express internally (and overtly) thoughts about his situation. This convergence eventually allows the development of thoughts that are not directly controlled by the child's environment. One begins to see why the authorities were displeased with the new psychology.

Equally objectionable was Vygotsky's interest in the poet's search for the exact word to express publicly the inchoate thoughts and feelings of an individual citizen. The last chapter of Thought and Language is prefaced by lines from Vygotsky's fellow 'cosmopolitan', Osip Mandelstam:

The word I forgot

Which once I wished to say

And voiceless thought

Returns to shadows' chamber.

When Vygotsky was dying of tuberculosis in a Moscow hospital, the secret police were already knocking on the door of Mandelstam's apartment. Yet it was precisely the poets, painters and musicians who nourished the people's capacity to resist in the darker days that were yet to come. It was Anna Akhmatova who wrote, during the siege of Leningrad:

And we will preserve you, Russian speech, The great Russian word.

John C. Marshall is in the Neuropsychology Unit, part of the Neuroscience Group at the Radcliffe Infirmary, Oxford $O X 26 \mathrm{HE}$, UK 